\title{
SAARC AS A TOOL OF REGIONALISM IN SOUTH ASIA: LESSONS FROM ASEAN
}

\author{
Tahir Ashraf ${ }^{1}$, Md. Nasrudin Md. Akhir ${ }^{2}$ \\ ${ }^{1}$ Asia-Europe Institute, University of Malaya, Kuala Lumpur \& \\ ${ }^{1}$ Department of International Relations, Bahauddin Zakariya University, \\ Pakistan \\ ${ }^{2}$ Department of East Asian, Studies, University of Malaya, Kuala Lumpur \\ (tahirmian1@siswa.um.edu.my)
}

\begin{abstract}
The South Asian Association for Regional Cooperation (SAARC) as a regional economic grouping in South Asia has not emerged as a viable and an efficient regional block such as the European Union (EU) and the Association of Southeast Asian Nations (ASEAN). Despite taking several initiatives in this regard, it has not achieved the desired objectives set forth at the time of its establishment. Over thirty years, it has become hostage to the Pakistan-India adversarial relationship. Through interviews with key informants (KIs), this article investigates the causes for the lack of momentum of SAARC and explores how ASEAN's path might offer lessons for SAARC. Adopting qualitative methods and content analysis this research finds the dominance of the Pakistan-India conflictual relationship as the key reason for the relative weakness of the SAARC. Moreover, the lack of implementation of SAARC declarations, conflicting issues between India and other neighbouring countries and the strict SAARC visa regime are important barriers to the enhancement of regional co-operation in South Asia. The article recommends that SAARC countries follow the ASEAN model and focus on the augmentation of regional cooperation while managing bilateral conflicts between them. In this regard, Pakistan and India, being the largest economies in South Asia, should also perform a role in enhancing bilateral economic cooperation to avoid the potential for bilateral conflict. The article also finds that bilateral economic co-operation between Pakistan and India has a spillover effect on the enhancement of regional economic cooperation in South Asia.
\end{abstract}

Keywords: Regionalism, SAARC, ASEAN, Pakistan-India, regional economic cooperation 


\section{Introduction}

Pakistan and India have an adversarial relationship since their inception in 1947. Despite engaging in war, they have taken several initiatives such as the Tashkent Declaration in 1966, the Simla Accord in 1972 and the Lahore Agreement in 1999 to mitigate bilateral conflict (Pattanaik, 1999). However, the bilateral relationship has not been transformed into cordial one, and trust deficit is prevailing the dynamics of bilateral interactions (Sen, 2014). In addition, South Asian countries including Pakistan and India initiated regional economic grouping named SAARC in 1985 for enhancement of regional economic cooperation. However, SAARC has been hostage by Pakistan-India conflict. This article attempts to analyse prospects for establishing sustained economic cooperation in South Asia as it happened to the cases of the European Union (EU), The North American Free Trade Agreement (NAFTA) and bilateral conflicts like Sino-Taiwan and Brazil-Argentina but specifically ASEAN. It also traces causes behind the failure of SAARC. In addition to it, this article suggests the lessons, which SAARC can learn from ASEAN.

Economic engagement between adversaries is not a new phenomenon in international politics. It has worked successfully in Europe especially between France and Germany after the Second World War. Moreover, economic linkages have performed a key role in development and progress of the Southeast Asian region and economic cooperation amongst members of ASEAN has not hostage by the conflicting issues existed between the participants. Economic cooperation between Argentina and Chile also has a spillover impact on the political and security relationship between them (Mares, 2000).

Given the rise of economic regionalism as well as globalisation in the post-cold war era, SAARC countries can move forward with the possible maximum economic engagement amongst them while putting controversial issues for a better time. How can SAARC move forward in this regard? This question is going to be addressed in this article.

Proponents of economic regionalism expansion in South Asia argue that Pakistan and India, being major economies and large countries of South Asia, should move forward and play their role in the rejuvenation of SAARC. SAARC can be revitalised while following functionalist approaches to regional integration. The functionalist approach argues for an increase in the institutionalisation of regional integration by internal demands for further integration such as increase of transactions i.e. intra-regional trade, a preferential regional trade agreement and free trade agreement within a 
particular region, and a collective response to the common problem. In these circumstances, states are expected to formulate new exercises or institutions to solve problems (Jetschke \& Murray, 2012).

The idea of SAARC was conceived when regionalism was getting popularity in the international arena, and it was successfully moving ahead in Europe and Southeast Asia. However, SAARC has also not been receptive to adapt copying of organisational design and to work with EU and ASEAN. Consequently, the 'existing set of ideas, belief system and norms, which determine an individual or social group's receptivity to new norms' (Jetschke \& Murray, 2012) or as Acharya calls it 'cognitive priors' (Acharya, 2009) appear to make institutional adaptations in South Asia as unlikely.

Researchers such as Ghosh (2013) and Khilnani (2012) are sceptic about prospects of success of the SAARC. India, being large in population, size, GDP and military spending has no match to its neighbours and fellow member of SAARC. Rather, India is more than the two-third of region's area and more than three-fourth of region's population, GDP and military spending (Ghosh, 2013). India does not have an interest in the region by its preeminence in the region and strives for global power. Because, South Asia, like what Ghosh (2013) argues, seems to emerge as larger market for neither India nor it can support in the emergence of India as a global power. The 65-page monograph considered as the high-profile Indian document called as Non-Alignment 2.0: A Foreign and Strategic Policy for India in the Twenty First Century has not even mentioned the word SAARC (Khilnani, 2012). Also, it is pertinent to note that the document emphasises that India cannot hope to arrive as great power status if it fails to manage conflicts within South Asia (Khilnani, 2012). However, the document underscores that South Asia has greater importance for India than any other region within Asia (Ghosh, 2013, p. 101).

Against this backdrop, a vital step towards regional integration was taken when Pakistan and India, being larger economies of SAARC, initiated South Asian Preferential Trade Agreement (SAPTA) in 1995. It was due to the realisation of Pakistan and Indian leadership that progress and development lie in cooperation and regional integration. SAPTA was considered as an important mechanism to reduce tariff duties and to remove non-tariff barriers. However, security issues and traditional rivalry between Pakistan and India did not allow them to move forward steadily in this direction. And, the process of regionalisation in South Asia also became slower.

An important development took place in 2004 when Pakistan and India decided to discuss 'eight identified issues including economic and commercial linkages' simultaneously under the 'Composite Dialogue' 
framework. Under the Composite Dialogue progress on one issue was not to be linked to the progress of another issue. Resultantly, several economic confidence-building measures (CBMs) were initiated, and reactivation of Joint Economic Commissions and Business Council in 2004 included among them. The initiative of the Composite Dialogue Process also has a great impact on the phenomenon of economic regionalisation of South Asia. SAARC countries including Pakistan and India concluded the South Asian Free Trade Agreement (SAFTA) that came into effect on January 1, 2006. According to SAFTA, SAARC region was to emerge as free trade area where duties and tariffs would be eliminated, and free movement of goods would become possible (South Asian Free Trade Agreement, 2004). As SAFTA has to be implemented in 2016, therefore, there is room for enhancing of regional trade in general and Pakistan-India bilateral trade in specific.

\section{Methodology}

The key research objective of the study is to identify the alternative approach to geopolitics to enable sustained peace in South Asia. Peace in South Asia can only be guaranteed by reducing the intensity of the Pakistan-India conflict, as it has dominated the region and its intricacies have increased with the inclusion of the overt nuclearisation of South Asia after India and Pakistan's nuclear detonation tests in May 1998. Pakistan and India have carried out several initiatives and concluded with different agreements, but geopolitical stumbling blocks have not allowed them to move forward. In this context, Pakistan and India need another approach. Therefore, this study focuses on exploring the prospects for enhancement of bilateral co-operation to lead to increasing the regional economic co-operation and manage the Pakistan-India bilateral conflict.

Table 1 Data of Interviewees (Key Informants)

\begin{tabular}{|c|c|c|c|c|}
\hline Interviewee & Pakistan & India & SAARC & ASEAN \\
\hline Traders/ Industrialists & 6 & 6 & $2^{*}$ & - \\
\hline Journalists & 4 & 4 & - & - \\
\hline Academicians/Experts & 4 & 4 & 2 & 2 \\
\hline Total & 14 & 14 & 4 & 2 \\
\hline
\end{tabular}

* Representatives from SAARC Chamber of Commerce \& Industry

The technique of in-depth interviews of KIs has been adopted in this study. In-depth interviews (IDIs) with KIs were conducted. The professional 
background and expertise of the KIs were reviewed carefully before conducting the IDIs with the KIs. Therefore, a purposive sampling method was used in this respect.

\section{Regionalism in South Asia}

The South Asian region consists of a large country India surrounded by medium and small countries like Pakistan, Bangladesh, Sri Lanka, Afghanistan, Nepal, Nepal, Bhutan and Maldives. India accounts for 80 percent of the region's GDP (IMF, October 2015) while Pakistan provides 11 percent, Bangladesh 9 percent, Sri Lanka 2 percent (Chandra \& Kumar, 2008). Despite being one of the most dynamic regions in the world, South Asia is also one of the least economically integrated. Intra-regional trade accounts for just 5 percent of total trade, compared with 25 percent in ASEAN (Regional Integration in South Asia, 2015). By building common interests across the borders, regional integration can enhance stability in this volatile region, which shares 44 percent of the world's poor and home to 570 million poor populations (Regional Integration in South Asia, 2015). On the other hand, it has 2.52 percent of the world's GDP while having 25 percent of the world's total populations (Bank, 2016). However, geopolitical tensions in South Asia mainly between Pakistan and India are producing blockages in regional integration.

South Asian countries will benefit substantially from greater integration through energy trade, commerce and river basin management. The most obvious gains are in the power sector, with connectivity enhancing system reliability, lowering costs and carbon emissions, and relieving debilitating shortages in all countries by enabling the sustainable development of the enormous hydro and gas-based power generation potential of the Himalayas and Central Asia. Afghanistan and Nepal have water resources that could potentially generate around 24,000 and 83,000 megawatts of electricity respectively (Regional Integration in South Asia, 2015).

\section{South Asian Association for Regional Cooperation (SAARC) as Manifestation of Regionalism in South Asia}

There were some earlier proposals for regional cooperation in Asia involving countries that are now considered as SAARC countries, such as the Asian Relations Conference in Delhi in April 1947, the Colombo Conference in 1954 and the Bandung Conference in 1955 (Ahmed, 2013). However, a small South Asian country's President Ziaur Rahman mooted the notion of SAARC in the 
early 1980s. President Ziaur who conceived of the idea of, and initiated actions for, regional cooperation in South Asia visited neighbouring countries for this purpose during 1979-80 to speak of the need to develop a framework for cooperation. With the failed attempt to join ASEAN, Bangladesh President sent his representatives to convey his special message to neighbouring countries along with his letter dated 2 May 1980 urging them to consider a proposal for a forum of regional cooperation akin to ASEAN (Sáez, 2011). Over the time in the early 1980s mostly South Asian countries had already become members of multilateral organisations, such as the British Commonwealth, the Non-Aligned Movement (NAM) and the United Nations Organisation (UNO). However, there was a lack of a regional organisation in South Asia to address issues at regional level.

In this backdrop, proposed member countries welcomed Bangladesh's proposal about the organisational framework for regional cooperation in South Asia. However, the leadership of India and Pakistan initially did not welcome this idea for different reasons. Pakistan had of the view that India would be able to establish its hegemony in South Asia from the platform of SAARC. India was also reluctant to support the initiative of any regional organisation like the proposed organisation mooted by Bangladeshi President because of a possible alliance of small countries of South Asia against India. And, this is what the then Indian Foreign Secretary responded to this initiative, as small powers of South Asia are likely to 'gang up' against India. However, both Pakistan and India were agreed to the establishment of a regional organisation without any traditional security agenda (Prasad, 1989). And, due to hectic diplomatic efforts dream of the establishment of a regional organisation in South Asia was realised.

\section{SAARC as Regional Economic Framework}

Owing to the Bangladesh President Ziaur Rahman's persuasion regarding regional cooperation in South Asia, countries of the region started the process of regional cooperation. As a result, a meeting of the Foreign Ministers was held in New Delhi on 1-2 August 1983. The delegates decided to adopt a Declaration on South Asian Regional Cooperation, which established basic objectives and principles for regional cooperation in South Asia and recommended some core institutional and financial arrangements. This 1983 Declaration is a significant document in the evolution of SAARC as, what Lawrence Sàez observes that 'many sections of the 1983 Declaration were copied literally in the SAARC Charter (Sáez, 2011). Seven South Asian 
countries namely Pakistan, India, Bangladesh, Bhutan, Nepal, Maldives and Sri Lanka gathered in Dhaka, Bangladesh on 8 December 1985 and agreed to establish an organisation known as South Asian Association for Regional Cooperation (SAARC Charter, 1985). Kathmandu was selected as SAARC headquarters. Afghanistan was added to SAARC as the eighth formal member in November 2005. Moreover, Australia, China, Iran, Japan, USA, Myanmar, Mauritius and South Korea are the countries that currently enjoy the status of observer. While an intergovernmental institution- European Union also holds the observer status in it.

SAARC leaders agreed to take all decisions at all levels by unanimity. It is pertinent to mention here that SAARC Charter under its Article $X$ prohibits member countries to discuss bilateral and contentious issues at this forum (SAARC Charter, 1985). The leaders of SAARC countries also decided to hold the Summit annually at the level of the Heads of State or Government at the location on a rotation basis. The leaders also committed to promoting peace and harmony among member states for the welfare of their masses.

The SAARC was a good opening for regional economic cooperation but with very aspiring objectives. However, SAARC member states could not maintain the aspirations that they manifested at the start of SAARC initiative. Resultantly, SAARC has become a lukewarm organisation with the objective of making declarations only. Reasons behind the lack of success of SAARC can be explained in the following section.

\section{Causes for Lack of Momentum of SAARC}

Though SAARC has not been reflected as successful regional association yet, it has generated a seemingly endless supply of initiatives, summit declarations, communiqués and expert-committee reports (Sáez, 2011). However, SAARC has become hostage by the Pakistan-India bilateral animosity since its inception in 1985. It was formulated with the objective of economic integration, yet it has not produced expected results due to the Pakistan-India conflict despite initiatives like SAPTA in 1993 and SAFTA in 2004. Despite having institutional constraints, which have worked as barriers yet, Pakistan-India conflictual relationship has operated as a key obstacle on the way to South Asian regionalism.

\section{Bipolar Conflictual Power Structure in South Asia}

Barry Buzan's Regional Security Complex Theory (RSCT) rightly explains 
SAARC's dilemma resulted by the bilateral conflict between Pakistan and India. According to Barry Buzan and Ole Wæver, RSCT is "defined by a durable pattern of amity and enmity in the form of regional or geographical patterns of security interdependence. The particular characteristic of Regional Security Complex is shaped by historic factors such as longstanding enmity or cultural linkage to a specific geographical region" (Buzan \& Waever, 2003). The bipolar conflictual power structure in South Asia resulting in "zero-sum notion of security" always works in Pakistan-India case creates complexes like 'we' and 'they' between Pakistan and India (Karim, 2015). This is blocking SAARC to emerge as an effective organisation on a regional basis. Therefore, Pakistan and India should adopt an approach, what Shahid Javed Burki quotes as "Pareto optimality- when given solution brings benefits to all participants in the transactions resulting into the plus-sum game" (Burki, 2009).

Geopolitical interests of Pakistan and India have always barred them from active participation in the process of regionalisation of South Asia. According to Barry Buzan and Ole Wæver, RSCT is defined as "a group of states where primary security concerns link together sufficiently closely that their national securities cannot reasonably be considered apart from one another" (Buzan \& Waever, 2003). Due to geopolitical considerations, Pakistan and India have blocked the successful functioning of SAARC while dashing the desired objectives of regional economic integration in South Asia. Therefore, Pakistan and India should embrace regional outlook instead of pursuing "country-centric approach" to convert South Asia into a viable regional economic block. Indian policy towards its small South Asian neighbours reflects the situation what renowned political theorist Hedley Bull terms, as "the deepest fears of smaller units in the global system are their larger units" (Hedley, 1977). Therefore, the role of Pakistan and India in SAARC has been hostage to their geostrategic interests.

Similarly, S.D. Muni has also identified the linkage between a widening strategic divide in the region predominantly between Pakistan and India and lesser regional cooperation in South Asia (Muni, 1985).

\section{Organisational and Internal Structural Impediments}

SAARC member countries established SAARC Secretariat to make the organisation as an efficient. Secretary General, appointed by the member countries on the alphabetical rotational basis, has to head the SAARC Secretariat for coordination among various institutional bodies. Likewise, 
SAARC Secretariat has Directors of Working Divisions nominated by member states. They perform their duties under SAARC Secretary General.

The staff of SAARC Secretariat seems to be a barrier, to an extent, in initiating the policies considered as essential for regional integration. The SAARC Secretariat operates on consensus-based approach. Therefore, representatives of their respective countries especially the Directors of Working Divisions do not support an initiative sponsored by the SAARC Secretariat, which may clash with the particular policy adopted by their respective countries.

Another important impediment to the progress of SAARC is a lack of technical staff nominated by the member states. Rather diplomatic staff dominates the SAARC Secretariat that does not have technical expertise. Mitrany also speaks about the important role of technical experts to accomplish the program of a regional organisation (Mitrany, 1944).

Often bilateral conflicts have resulted in the postponement of annual Summit meetings of SAARC and delayed implementation of its programmes not in all areas rather in particular areas. The scheduled 1989 SAARC Summit was postponed due to the then ongoing Sri Lanka-India conflict. Similarly, $11^{\text {th }}$ SAARC Summit was postponed from 1999 to 2002 due to the post-Kargil episode in Pakistan-India relations. And, the $12^{\text {th }}$ SAARC Summit had also been postponed from 2003 to 2004 due to Indian allegations against Pakistan for supporting cross-border terrorism. Consequently, in roughly 30 years (1985-2015), SAARC has managed to organise twenty meetings instead of one per year.

\section{SAARC and Regional Economic Cooperation}

The primary objective of the SAARC, according to Article I of the SAARC Charter is "to promote the welfare of the peoples of SOUTH ASIA and to improve their quality of life" (SAARC Charter, 1985). In order to achieve this objective, along with other objectives mentioned in the charter, the SAARC leaders at its first summit meeting displayed their conviction about the benefits of regional cooperation in these words "that regional cooperation among the countries of SOUTH ASIA is mutually beneficial, desirable and necessary for promoting the welfare and improving the quality of life of the peoples of the region" (SAARC Charter, 1985). Therefore, SAARC had been responding appropriately for the initiate and strengthened economic cooperation among its member states. However, it has not produced desired results due to multiple factors mainly the Pakistan-India conflict. 
The focus of this section is to investigate SAARC's initiatives regarding fostering of regional economic cooperation with a special focus on trade. During the formative phase, SAARC could not take concrete steps towards significant achievements owing to misperceptions of its member states about each other. However, it was able to take tangible steps for cultivating economic cooperation among the member states in the succeeding years. Keeping in view the necessity of institutionalisation of economic cooperation, the ninth meeting of the Council of Ministers held in Malé, Maldives a highlevel committee on economic cooperation named as Committee on Economic Cooperation (CEC) was established during the ninth meeting of the Council of Ministers. The membership of CEC comprised of trade and commerce secretaries from all the eight SAARC member states.

One of the important contributions of the CEC is to recommend the idea of the creation of an Intergovernmental Group (IGG) to formulate and seek government consultations regarding liberalisation of trade in South Asia and enactment of rules under that specific trade regime. SAPTA and consequently SAFTA are the outcomes of this CEC.

The SAARC Chamber of Commerce and Industry (SCCI), established in 1992, has also contributed towards promotion of regional economic cooperation among the SAARC member states. Quoting M.H. Syed (Sáez, 2011, 2014) points out that the SCCI was 'instrumental in bringing into fruition the SAARC Preferential Trade Agreement (SAPTA)'.

SAFTA was eventually signed on 6th January 2004 during the 12th SAAARC Summit held in Islamabad, Pakistan. The Agreement became operational in July 2006, following ratification by all the SAARC member states. Under SAFTA, SAARC is supposed to gain its target of zero duties across South Asia while helping SAARC emerging as the Economic Union. However, the success achieved under the treaty has been quite limited, and the large sensitive (sometimes called negative) lists maintained by member countries are considered as reasons for SAFTA being ineffectual (Taneja, Ray, Kaushal, \& Chowdhury, 2011). However, member countries are purging these lists under an ongoing process.

Nevertheless, to achieve the status of an Economic Union, there are stages such as a customs union that have to be achieved before this. Regarding stages towards an economic union, SAARC has moved from preferential trade area to free trade area. However, it still needs to ensure the success of free trade in South Asia before proceeding towards a customs union in South Asia, and a common market. There are some obstructions to making of South Asia as free trade region such as impartial standards of goods and resolution of 
trade-related disputes. Lawrence Sàez has characterised SAFTA as undeniably the most important intraregional trade agreement in South Asia and is, arguably, the most significant achievement of SAARC (Sáez, 2011, 2014).

Economic cooperation under any bilateral or multilateral forum is an ever-evolving process. And, SAARC is no exception to it. A remarkable move is the creation of South Asian Forum (SAF) that was launched in April 2011 in New Delhi on the pattern of the World Economic Forum based in Davos, Switzerland (Ahmed, 2013). The SAF aims to provide a forum to academicians, economic managers, public figures, business leaders, politicians and representatives of civil society from South Asia to deliberate on regional economic cooperation in South Asia. It is premature to say about the contribution of SAF, yet it reveals willingness of the SAARC countries to adopt inclusive approach towards regional economic cooperation while taking into account diverse segments of society.

\section{SAARC: An Assessment}

In its almost thirty years of history, it is not realistic to believe that its achievements as a regional organisation are a story of failure. During these years SAARC's performance has been mixed, and its political leaders have met regularly particularly on informal discussions to address their mutual problems. These informal discussions produced some significant results in South Asia. The informal talks between the Pakistani and Indian Prime Ministers at the second SAARC Summit meeting at Bangalore in November 1986 led to the dilution of tension between the two countries on the issue of India's military exercise, Operation Brass Tacks, on the Pakistan-India border. Also, the India-Sri Lanka talks at the 1987 SAARC Foreign Ministers' meeting led to their accord on the Tamil problem. Similarly, in the wake of an informal meeting and discussion between Nawaz Sharif and P.V. Narasimha Rao Prime Ministers of Pakistan and India respectively, at Davos (Switzerland) in 1992, the Pakistani government took action to prevent the move of the JKLF to cross the ceasefire line in Kashmir later that year. The Davos meeting could only become possible owing to an earlier informal agreement between the two leaders at the Sixth SAARC summit meeting in Colombo in December 1991. In this way, SAARC, on several occasions, has displayed its expanding role. However, it would emerge as a more vibrant regional economic organisation provided that Pakistan-India bitter relationship becomes normalised. And, bilateral economic cooperation between Pakistan and India is essential to attain normalcy between them. 
The recognition of the importance of the process of an informal discussion is one of the principal achievements of the SAARC. Here, the SAARC can learn from ASEAN's working where member states hold discussions informally before the start of formal meetings (Interview was conducted with former ASEAN official on 26 August 2016). The Heads of State or Government at the Ninth SAARC Summit, for the first time, agreed that a process of informal political consultations would prove useful in promoting peace, stability, amity and accelerated socio-economic cooperation in the region. The leaders echoed this intent during their Tenth and Eleventh Summits held in Colombo and Kathmandu respectively (SAARC, 1998, 2002).

In an insightful assessment of pattern of regional cooperation among the South Asian countries under the framework of SAARC, Lawrence Sàez, a professor of international relations and expert on South Asian affairs at SOAS, University of London, argues that;

\begin{abstract}
"SAARC appears to have adopted the Nordic model of regional cooperation; that is, an avoidance of 'constitutional approach' an understanding that the national structure would remain the unalterable political basis for co-operation that would be directed to areas of relatively 'low' political content, and the exclusion of areas of 'high' political content (such as national security) from regional cooperation" (Sáez, 2011, p. 107).
\end{abstract}

Despite being the prey to critics regarding its, efficacy SAARC has been viewed among government functionaries and diplomats from South Asia as a respected organisation (Sáez, 2011). The emergence of SAARC has been portrayed as a significant development and "its existence has certainly provided an opportunity for the policymakers, administrators, and experts to meet regularly and hold informal dialogues on bilateral and regional issues." Similarly, "practice of informalism and behind-the-scene discussions among the political leaders on various SAARC forums has helped contain many difficult situations and has contributed to the beginning of a process of the confidence-building process in South Asia" (Dash, 1996). Underlining the substantial role of SAARC S. D. Muni proposes that without SAARC "the deterioration in the regional strategic environment would have been greater and moved faster" (Muni, 1985). Furthermore, he points out that "the SAARC's Charter forbids member countries to discuss bilateral and contentious issues, and so tackling the aggravated subject of regional cooperation in counter- 
terrorism is not entirely within its purview" (Interview was conducted on 26 March 2016).

It is pertinent to mention that SAARC declarations, conventions and policies are an indicative of the fact that it has managed not only to develop consensus on non-controversial issues but has also implemented meaningful initiatives such as SAARC Food Bank, the South Asian University and SAARC Development Fund (Ahmed, 2013).

However, traditional animosity between Pakistan and India has not allowed SAARC to move ahead with the pace required for the earlier emergence of SAARC as an economic grouping. In this context, this study attempts to trace the prospective role of SAARC in augmenting economic cooperation between the two major economies of South Asia. The primary data of this study anticipates the minimal role of SAARC in enhancing economic cooperation between Pakistan and India as well as managing their bilateral conflict. Figure 1 displays the prospective role of SAARC in enhancing economic cooperation between Pakistan and India.

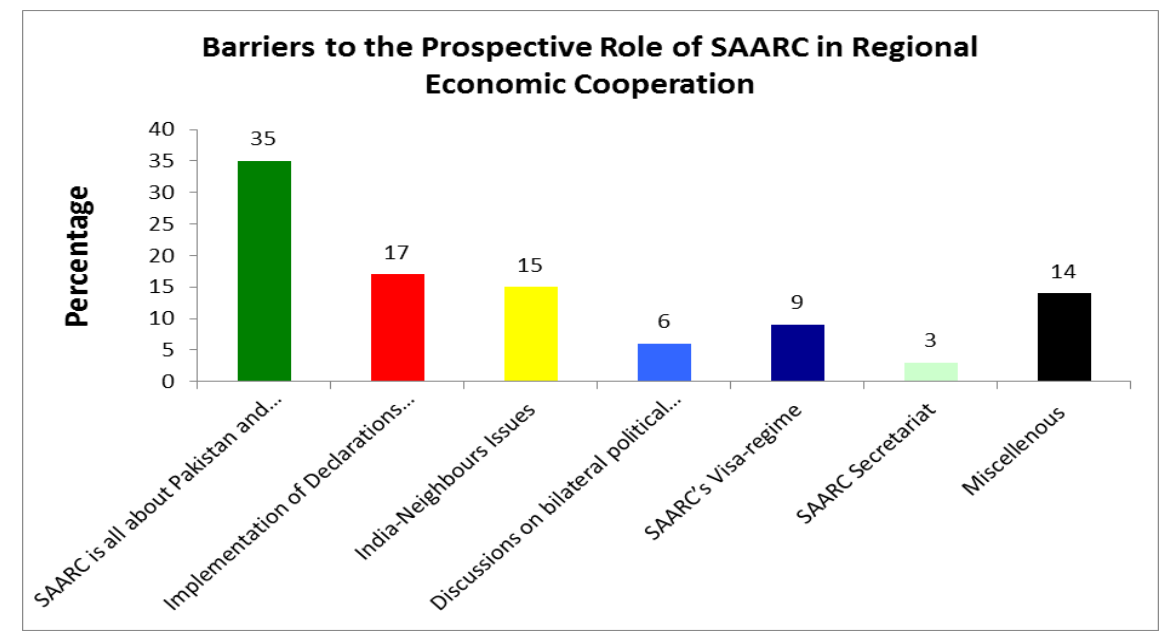

Figure 1 Barriers to the Prospective Role of SAARC

Source: Authors' calculations based on interviews with KIs.

Based on interviews with KIs, this study finds that SAARC has a minimal role in enhancing economic cooperation between Pakistan and India because the Pakistan-India bilateral relationship dominates the SAARC and the bilateral adversarial relationship is a key hurdle. Article 10 of the Charter of SAARC prohibits member countries to raise bilateral issues at the forum of SAARC (SAARC Charter, 1985). Therefore, Pakistan and India can play their role in making SAARC as an effective economic grouping instead of SAARC's 
role in enhancing Pakistan-India bilateral trade links. Also, implementations of SAARC declarations are another significant cause for lesser role of SAARC for integration of the region. India's bilateral issues with its neighbours are also working as barriers to making SAARC as an effective regional economic block. Moreover, strict visa regime among SAARC countries may be another barricade to the emergence of SAARC as a successful economic association. Figure 1 exhibits the issues that are holding SAARC back, and these issues are not allowing SAARC to play its role in enhancing economic cooperation between Pakistan and India.

\section{Economic Regionalism in Europe and Southeast Asia (ASEAN) as Lessons for Economic Regionalism in South Asia}

The process of economic and political integration and security cooperation, a prevalent feature of contemporary international relations, started in its nascent form in Europe. Evolved through a lengthy process and resultantly emerged as the European Union (EU) is now considered as a reference point for the successful regional organisation. Started from a humble organisation 'set up to coordinate European trade in coal and steel it has been evolved as a suprastate institution (Burki, 2009). Terming the Europe's history as a lesson for everybody Jokela has pleaded the impression of European Union as a reference point (Jokela, 2009). The European Union was not in similar form just after the end of Second World War. Though the process of European economic regionalism was initially slow, its undoubted success; and an institutionalised relationship between its members have made the European Union as 'the most integrated regional arrangement' (Beeson, 2005). The internal urge for cooperation was a compelling reason yet America as an external factor was also a key push factor. With the emergence of Soviet Union as the chief proponent of a rival ideology and the beginning of SovietAmerican superpower rivalry in the Cold War from 1947-48, the US became a passionate sponsor of Euro-Federal solution (Dedman, 2006). The US did not want to allow the Soviet Union to establish its clout in Europe. Therefore, geopolitical considerations were also the main cause behind the emergence of European regionalism.

European economic regionalism initially started with the notion of reconstruction and recovery of war-stricken European region under the Marshall Plan. Americans instituted the Marshall Plan cost of US\$ 49 billion with the objective to boost ailing European economies resulted by devastations 
of the Second World War. It was also seen as key to the preservation of political democracy (De Long \& Eichengreen, 1991).

Some scholars considered the role of the US as crucial and term American role as a proponent of economic regionalism in Europe as part of its grand strategy of containment against Soviet political and ideological influence in the region (LaFeber, 1999; Milward, Brennan \& Romero 2000; and Beeson, 2005). While quoting Gaddis, Beeson points out that European economic regionalism was a fundamental part of America's containment strategy and its objective was to establish 'countervailing centres of powers as bulwarks against the Soviet expansionism' (Beeson, 2005). LaFeber argues for long-time existing American intention to pursue simultaneously strategic and economic objectives (LaFeber, 1999). On the other hand, scholars like Folly consider the role of Britain and France as crucial in sponsoring the idea of panEuropean security framework (Folly, 1988). Likewise, France played a key role in establishing European Coal and Steel Community (ECSC) that cemented the process for extensive integration.

It is relevant to point out here that the idea of regional cooperation in the form of ECSC emerged in the wake of shortage of coal production in Western European countries. Furthermore, these countries considered it as a common issue. German coal production was a little more than half of the level where it was before the beginning of Second World War. Likewise, Belgian and Dutch production was 20 per cent lower while British production was 10 percent lower than production at the pre-war stage in 1938 (De Long \& Eichengreen, 1991). Coal shortages led to the shutdown of almost a fifth of coal burning and electricity-using industry in 1947. Similarly, Western European industrial production in 1946 was 60 per cent and 70 per cent in 1947 of the pre-world war second level (De Long \& Eichengreen, 1991). Getting benefits from cooperation from the establishment of ECSC, a common market for coal and steel, under the Treaty of Paris in 1951, the European countries realised to expand this cooperation to other sectors. Resultantly, cooperation progressed further through different stages from the European Economic Community (1958-86) to the European Community (1986-1991) to finally the European Union (EU) since Maastricht. In addition, its primary concern has been with the commercial issues and related policies.

Regarding the role of the United States of America (USA) in the development of war-stricken Europe and the establishment of a regional organisation for economic cooperation, it can be said that having the strong support of the USA, war-raged European economies started to stand together to move forward and recover from the aftermath of Second World War. While 
quoting Karl Deutsch, Alan S. Milward argued that the growth of 'community' depended on the sudden emergence of an American strategic interest in Western Europe and active cooperation of the United States and Western Europe within the new post- war international organisations (Milward, Brennan, \& Romero, 2000). The key purpose of the Schumann Plan that provided a scheme for economic integration of the European region was to provide a political structure to bind former adversaries into a common framework. With the American influence and support 'German Question' was resolved and Germany was included in the emerging post-world war second apparatus.

Establishment of security architecture was also a central feature of European regionalism. An initiative of Europe Defence Community (EDC) was taken in 1950 but competing for national interests of UK, France, and Germany delayed the ratification process. However, the long saga of EDC ended in August 1954 when the French National Assembly even did not accord it approval for debate. And, the decease of EDC conclusively cleared the way for further negotiations on European economic integration (Dedman, 2006). A new security apparatus North Atlantic Treaty Organisation (NATO), established in 1949, has dominated the Western Europe for the next halfcentury and redefined geopolitical identities of the region. Moreover, America became an important part of the emerging new security structure, which it perceived as an important component of the larger framework for containment of the Soviet Union. Contrary to European regionalism, Southeast Asian and South Asian regionalism did not enjoy the US support at their outset. Rather, American attitude towards European, unlike towards the East Asian and South Asian, were based on equality and respect.

Comparatively slower in pace regarding institutionalisation of the political cooperation, Southeast Asian regionalism has emerged as a model for developing countries. Established in 1967 the ASEAN has worked as an important vehicle for discussing their collective interest and integrating the region. Unlike the American support exercised by EU and NATO at the time of their inception, ASEAN countries were not getting any potential support from the USA. Moreover, divisions within the East Asia during Cold War era also worked as an impediment to Southeast Asian regionalism. In addition, America was establishing links with Southeast Asian countries at bilateral basis instead of multilateral basis. This act of America became an impediment in enhancing regionalism in Southeast Asia (Beeson, 2005). Acharya considers, whatever limited regional integration among the Southeast Asian countries, as a result of American containment policy against China (Acharya, 2001). 
However, regionalism in Southeast Asia moved ahead despite American positions while financial crisis erupted in East Asia in 1997 also played as a catalyst in enhancing Southeast Asian regionalism and national economies of Southeast Asian countries were to be integrated into a wider international political economy (Terada, 2003; Webber, 2001).

Scholars and observers have also opined that to what extent ASEAN has achieved influence from EU. The notion of EU as model power is assumed on the premise that 'Europe's history is a lesson for everybody (Jokela, 2009). The standard interpretation is that the European Union has emerged as a form of integration framework that has brought peace and prosperity to a region, which was previously devastated by war between the European states. However, Wong claims that the European Union has exerted some power over ASEAN but only as a reference point, not as model power. The EU serves as a passive reference point for ASEAN because its influence is not very active (Wong, 2012). And, this reference points entreaties to the 'rational, utilitymaximizing calculations of the actor' instead of working on the emotional index (Wong, 2012).

Rising Regionalism in Americas (North, South and Central) and expansion of European Union towards Eastern Europe also urged ASEAN countries to share regional approach and motivated them to adopt regional institutions comprising East Asia (Terada, 2003). Having benefits of regionalism ASEAN countries are extending their cooperation at the forum of ASEAN + 3 (Japan, Korea and China) and moving to adopt an approach of 'East Asian regionalism'.

\section{Reflections}

Bilateral economic cooperation between Pakistan and India and regional economic cooperation in South Asia from the platform of SAARC are two sides of the same coin. Both are interlinked to the extent that they are complimentary to each other. More importantly, Pakistan-India economic cooperation has greater prospects for spillover towards an increasing regional cooperation at the SAARC-level (De, Raihan, \& Ghani, 2013; Husain, 2013; Kemal, Abbas, \& Qadir, 2002; Khan, 2009; Pasha \& Imran, 2012; Raihan \& De, 2013). Moreover, improved economic relations between Pakistan and India would help improving South Asia's footing in the world economy (Burki, 2009, 2010, 2011; Raihan \& De, 2013). Nonetheless, augmenting of regional economic cooperation has been a hostage, largely, by the Pakistan-India conflictual relationship. Against this backdrop, it is essential to address Pakistan-India 
conflict simultaneously as well as moving towards fostering of regional economic cooperation in South Asia as ASEAN members have adopted the path to managing their bilateral conflicts and settled some of the border disputes amongst them while not permitting regional economic cooperation to become hostage by bilateral conflicts. ${ }^{1}$ The ASEAN member states have managed to build confidence and develop an understanding to a variety of issues between them through formal and non-formal discussions between the leaders, ministers and senior officials of the member states (Amer, 1999). In this regard, the central element of ASEAN's approach to avoiding conflict and restrain the existing conflict has been 'consultation processes termed as musyawrah. The central character of this 'consultation process' is an informal discussion that has been evolved through the practice applied in villages of Indonesia, Malaysia and the Philippines (Amer, 2000). The aim of the process of 'musyawrah' is to attain unanimous decisions which are called as 'mufakat'(Amer, 2000). In this way, the ASEAN model of conflict management has a great significance for the SAARC member-states to enhance economic cooperation in South Asia (Jetly, 2003). To enhance intra-regional economic cooperation in South Asia it is appropriate for Pakistan and India, being larger economies in the region, to manage bilateral conflict and transform an overall nature of SAARC from a moribund organisation to a viable economic grouping.

\section{Conclusion}

The Economic arrangement between adversaries is an old phenomenon in international politics. However, SAARC cannot emerge as an efficient economic block over the last thirty years mainly due to the dominance of the Pakistan-India bilateral conflict in the region. Barry Buzan's RSCT appropriately elucidates SAARC's predicament resulted from the bilateral conflict between Pakistan and India. Views of the interviewees conducted for this research also reflect that Pakistan-India bilateral conflictual relationship mainly dominates the SAARC. Furthermore, lack of implementation of SAARC declarations, India's conflicting issues with its neighbours and the

1 Malaysia-Indonesia conflict; Malaysia-Thailand conflict; Indonesia-Thailand; LaosVietnam; Thailand-Cambodia conflict; Malaysia-Singapore conflict; Malaysia-Philippine; Myanmar-Thailand; Laos-Myanmar; Thailand-Vietnam and Malaysia-Vietnam are managed by them, and ASEAN countries have not permitted ASEAN to become hostage by their bilateral conflicts. 
SAARC's strict visa regime are barricades in the strengthening of regionalism in SAARC countries.

Therefore, an impetus may be given to bilateral economic cooperation between Pakistan and India for increasing regional cooperation among the SAARC member-states. In this regard, ASEAN's consensus-based 'consultation process' can be used as a good starter for SAARC. ASEAN's way of holding informal discussions between the ministers and senior officials and the leaders of the ASEAN member-states at the summit level may be adopted as a model for SAARC countries. Furthermore, SAARC member-states may move forward to enhance regional economic cooperation while managing bilateral conflicts to the extent that it may be halted to the better time to come. Furthermore, Pakistan and India, being larger economies in South Asia, have a great responsibility to manage their bilateral conflict and emphasise their focus upon increasing economic engagements between them.

It is also pertinent to note that SAARC declarations should be implemented in its true spirit because this is another workable mechanism to for augmentation of confidence among the member-states.

\section{References}

Acharya, A. (2001). Constructing a security community in Southeast Asia: London: Routledge.

Acharya, A. (2009). Whose ideas matter?: agency and power in Asian regionalism: Cornell University Press.

Ahmed, Z. S. (2013). Regionalism and Regional Security in South Asia: The Role of SAARC: Ashgate Publishing, Ltd.

Amer, R. (1999). Conflict management and constructive engagement in ASEAN's expansion. Third World Quarterly, 20(5), 1031-1048.

Amer, R. (2000). Managing border disputes in Southeast Asia. Kajian Malaysia, Journal of Malaysian Studies, 18(1-2), 30-60.

Bank, W. (2016). India: The World Bank.

Beeson, M. (2005). Rethinking regionalism: Europe and East Asia in comparative historical perspective. Journal of European Public Policy, 12(6), 969-985.

Burki, S. J. (2009). South Asia: Overcoming the Past, Meeting the Challenges of the Present and Availing the Opportunities of the Future. ISAS Working Paper(60).

Burki, S. J. (2010). ISAS Working Paper. (110), 1-10. 
Burki, S. J. (2011). South Asia in the New World Order: The role of regional cooperation. New York: Routledge.

Buzan, B., \& Waever, O. (2003). Security Complexes: A Theory of Regional Security.

Chandra, R., \& Kumar, R. (2008). South Asian Integration Prospects and Lessons from East Asia Ramesh Chandra Rajiv Kumar. (202).

Dash, K. C. (1996). The political economy of regional cooperation in South Asia. Pacific Affairs, 185-209.

De Long, J. B., \& Eichengreen, B. (1991). The Marshall Plan: History's most successful structural adjustment program. Retrieved from

De, P., Raihan, S., \& Ghani, E. (2013). What does MFN trade mean for India and Pakistan? Can MFN be a Panacea? Can MFN be a Panacea?

Dedman, M. (2006). The origins and development of the European Union 1945-1995: a history of European integration: Routledge.

Folly, M. H. (1988). Breaking the vicious circle: Britain, the United States, and the genesis of the North Atlantic Treaty. Diplomatic History, 12(1), 5977.

Ghosh, P. S. (2013). An Enigma that is South Asia: India versus the Region. Asia-Pacific Review, 20(1), 100-120.

Hedley, B. (1977). The Anarchical Society: A Study of Order in World Politics. London: Macmillan.

Husain, I. (2013). Managing India-Pakistan Trade Relations. In M. Kugelman, \& Hathaway, Robert M. (Ed.), PAKISTAN-INDIA TRADE: What Needs To Be Done? What Does It Matter? (pp. 59-74). Washington, DC:: The Wilson Centre.

IMF. (October 2015). South Asia: Robust Growth Amid Global Uncertainty. South Asian Regional Update.

Jetly, R. (2003). Conflict management strategies in ASEAN: perspectives for SAARC. The Pacific Review, 16(1), 53-76.

Jetschke, A., \& Murray, P. (2012). Diffusing regional integration: the EU and Southeast Asia. West European Politics, 35(1), 174-191.

Jokela, J. (Ed.) (2009). The European Union as International Actor: Europeanization and Institutional Changes in the light of the EU's Asia Policies. Farnham: Ashgate, United Kingdom.

Karim, A. L. G. R. (2015, 20 October 2015) Prospects for Enhancing of SAARC /Interviewer: T. Ashraf.

Kemal, A. R., Abbas, M. K., \& Qadir, U. (2002). A Plan to Strengthen Regional Trade and Cooperation in South Asia. Trade, Finance and Investment in South Asia, 239-319. 
Khan, M. S. (2009). India-Pakistan Trade: A Roadmap for Enhancing Economic Relations. Economics, 1975(76).

Khilnani, S. (2012). Nonalignment 2.0: A foreign and strategic policy for India in the twenty-first century: Centre for Policy Research.

LaFeber, W. (1999). The tension between democracy and capitalism during the American century. Diplomatic History, 23(2), 263-284.

Mares, D. R. (2000). Exploring the Impact of Economic Cooperation on Political and Security Relations between Argentina and Chile. Retrieved from

Milward, A. S., Brennan, G., \& Romero, F. (2000). The European rescue of the nation-state: Psychology Press.

Mitrany, D. (1944). A Working Peace System: An Argument for the Functional Development of International Organization, by David Mitrany,...[2nd Printing, Enlarged.]: Royal Institute of international affairs.

Muni, S. D. (1985). SAARC: Building Regionalism from Below. Asian Survey, 25(4), 391-404.

Pasha, H. A., \& Imran, M. (2012). The prospects for Indo-Pakistan trade. Lahore Journal of Economics, 17(Special Edition), 293-313.

Pattanaik, S. S. (1999). Indo-Pak relations: Need for a pragmatic approach. Strategic Analysis, 23(1), 85-110.

Prasad, B. (1989). Regional cooperation in South Asia: Problems \& Prospects: Stosius Inc/Advent Books Division.

Raihan, S., \& De, P. (2013). India-Pakistan economic cooperation: Implications for regional integration in South Asia. Commonwealth Secretariat, London. Regional Integration in South Asia. (2015). Retrieved from worldbank.org

SAARC. (1998). Declaration of the Tenth SAARC Summit Colombo 31 July 1998. Kathmandu: SAARC Secretariat Retrieved from http://www.saarcsec.org/userfiles/Summit Declarations/10 - Colombo - 10th Summit 1998.pdf.

SAARC. (2002). Declaration of the Eleventh SAARC Summit. Kathmandu: SAARC Secretariat Retrieved from http://www.saarcsec.org/userfiles/Summit Declarations/11- Kathmandu 11th Summit 2002.pdf.

SAARC Charter. (1985). Kathmandu Retrieved from http://www.saarc-sec.org.

Sáez, L. (2011). The South Asian Association for Regional Cooperation (SAARC): An Emerging Collaboration Architecture: Routledge.

Sáez, L. (2014). SAARC, the Road-Map for Economic Co-operation from a European Perspective The Merits of Regional Cooperation (pp. 71-75): Springer. 
Sen, R. (2014). India's South Asia Dilemma and Regional Cooperation: Relevance of Cultural Diplomacy. Strategic Analysis, 38(1), 68-78.

South Asian Free Trade Agreement. (2004). Retrieved from http://www.saarcsec.org/userfiles/saftaagreement.pdf.

Taneja, N., Ray, S., Kaushal, N., \& Chowdhury, D. R. (2011). Enhancing intraSAARC trade: pruning India's sensitive list under SAFTA. Working Research Paper-255, Indian Council for Research on International Economic Relations, New Delhi.

Terada, T. (2003). Constructing an 'East Asian concept and growing regional identity: from EAEC to ASEAN+3. The Pacific Review, 16(2), 251-277.

Webber, D. (2001). Two funerals and a wedding? The ups and downs of regionalism in East Asia and Asia-Pacific after the Asian crisis. The Pacific Review, 14(3), 339-372.

Wong, R. (2012). Model power or reference point? The EU and the ASEAN Charter. Cambridge Review of International Affairs, 25(4), 669-682. 